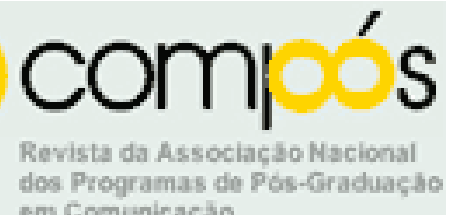

Este artigo foi publicado na edição 1, em dezembro de 2004, da revista eletrônica e-compós: http://www.compos.org.br/e-compos

\title{
RISCO E SEGURANÇA: A CONSTRUÇÃO DO FUTURO NO DISCURSO DA COMUNICAÇÃ̃O ${ }^{*}$ )
}

Claudio Bertolli Filho $\left.{ }^{* *}\right)$

UNESP

A constatação de um tempo novo, pautado menos por rupturas do que pela ampliação do escopo das intervenções científicas e a proliferação de renovadas tecnologias, tem se desdobrado na multiplicação de questionamentos acerca da vida social. A partir disso, detecta-se um misto de expectativas ufanistas e declarações niilistas que, em conjunto, contaminam os diversos setores da vivência humana e favorecem seminais releituras do pretérito e do presente, assim como instigam projeções sobre o porvir individual e coletivo.

Sob a rubrica de pós-modernidade, alta modernidade ou ainda modernidade tardia, anuncia-se um contexto propenso mais a amálgamas do que a sínteses, alimentando contínuas e persistentes ambigüidades e também um mal-estar que se infiltra em todas as instâncias do cotidiano e em suas expressões culturais. A busca de explicações sobre quem somos e para onde rumamos tem alimentado uma vasta bibliografia que tenta decifrar os enigmas propostos pela conjuntura atual.

Coube a Anthony Giddens (2002) tecer uma das mais vigorosas interpretações sobre os impasses contemporâneos, sugerindo que os encaminhamentos disponíveis tanto no plano global quanto nacional, local e individual passam concomitantemente por dois circuitos extremos. Tais rotas, apesar de antagônicas, complementam-se, sendo modeladas pelas concepções de segurança e de risco em relação à sociedade e suas instituições. 
O primeiro desses caminhos articula-se com a legitimação de tudo ou pelo menos de boa parte do universo considerado próprio da pós-modernidade; o cultivo, não sem críticas e reticências, da sensação de segurança enfatiza a positividade dos novos laços de sociabilidade, a autonomia e relativa acuracidade das decisões político-econômicas, os resultados benéficos da presença maciça da Ciência e da Tecnologia no dia-a-dia, enfim, busca instigar a adesão às instituições ao mesmo tempo produzidas e produtoras da realidade social. O segundo roteiro, em oposição, recobre-se de cautelas, enfatizando a noção de risco tanto nas avaliações do presente quanto do futuro; nessa operação, confere caráter potencialmente danoso a uma série de instituições, agentes sociais e saberes que em épocas anteriores não eram alvos de intensos receios, expondo as desconfianças e temores em relação aos elementos basilares da sociedade. A vida contemporânea flui, pois, pendente entre um e outro pólo perceptivo, conferindo contornos próprios aos novos esquemas de sociabilidade e aos suportes articulados no plano da cultura.

A 'cultura da segurança', sinônimo quase perfeito de alta dose de confiança nas grandes estruturas da sociedade e em seus produtos culturais, viabiliza comportamentos sociais produtivos porque promotores da pronta revisão e imediata circulação de idéias e mercadorias, nutrindo esperanças de que aquilo que serve para hoje, perderá total ou parcialmente sua utilidade amanhã; nessa via, defende-se que a contínua e rápida renovação favorece o aperfeiçoamento humano, social, político e econômico. Rumando em sentido contrário, a 'cultura de risco' tem enfatizado os perigos do progresso acalentado, já que o universo e seus personagens humanos são analisados como potencialmente capacitados para minar a existência, conduzir a calamidades que, se não prometem o próprio apocalipse, pelo menos acenam com a possibilidade de problemas de difíceis, se não de impossíveis soluções.

Giddens (2002:25) também defende o suposto segundo o qual o período que ele próprio insiste em declarar como sendo uma fase da modernidade busca apresentar-se essencialmente como 'uma ordem pós-tradicional' no sentido que, ao redefinir as orientações espaço-temporais, 'afasta a vida social da influência de práticas e preceitos preestabelecidos’. A apologia implícita da presunção de que 'tudo que é sólido desmancha no ar', preconizada desde o século XIX por Marx e Engels (1996) e retemperada por Berman (1986), no entanto, conta com 
limitações bem claras, as quais são assumidas pelo sociólogo britânico. Se a teia cultural do tempo presente busca romper com as amarras impostas pelo processo histórico, ela também é conseqüência dele, abrigando em seus interstícios o 'tradicional' e o 'moderno', o que deixa às claras o momento de transição que todos nós experimentamos, não sem uma boa dose de desconforto.

A ânsia pelo eternamente novo situa quase que automaticamente a Ciência e suas derivações tecnológicas como elementos constitutivos de uma das principais instituições que caracterizam a problemática pós-moderna, abrigando em seu bojo as noções de segurança e risco e, através disto, permitindo formulações polifônicas sobre como tais setores estão articulados no processamento do presente e do futuro humano. Assim, por um lado a herança positivista, ainda incontestavelmente vigorosa nas falas dos pesquisadores, continua a reiterar que as expressões científicas, aqui emblematizadas pelos saberes e práticas médico-biológicas, produzem suportes encaminhadores do progresso, sustentando que a Ciência como um todo acalenta como objetivo maior o aperfeiçoamento da existência humana, quer em sua dimensão social quer no plano biológico (Bernard, 1998). Em outra direção, apregoa-se que a cultura pós-moderna é moldada pelo desencantamento em relação ao poderio científico; o conhecimento forjado nos laboratórios e nos debates acadêmicos corre o risco de condenar a todos a um futuro sombrio, mencionando-se como exemplo favorito a 'nova eugenia' que, em uma de suas pontas, resgatou o velho pesadelo de uma humanidade tecnificada e condenada a privilegiar os biologicamente 'mais aptos' (seja lá o que este rótulo possa significar) em detrimentos dos 'fracos' (Black, 2003). As análises no campo da Ciência que postulam que 'jamais fomos modernos' (Latour, 2000) coadunam-se com a desconfiança de que a Ciência está mais apta para destruir do que para glorificar a vida, alegando-se inclusive que o 'berço simbólico’ da pós-modernidade conta com dia e hora impostos pelos cientistas: 8h15 da manhã do dia 6 de agosto de 1945, instante em que o primeiro artefato nuclear foi detonado sobre uma coletividade humana (Santos, 1986: 20)1.

É nesse cenário nebuloso que, ainda segundo Giddens, a idéia de sina, mesmo que destituída de sua dimensão fatalista, aflora como um dos elementos persistentes nos registros pós-modernos, constituindo-se em um dos itens 
fundantes das negociações das identidades contemporâneas e das estratégias mobilizadas para a interpretação do presente e dos apregoamentos sobre o tempo futuro. A ampla autonomia conferida ao Homem em suas tomadas de decisões permite o delineamento de um destino que está em nossas mãos, colocando em tela a especificidade ética dos indivíduos, dos agrupamentos sociais e dos arranjos institucionais. Em continuidade, não é exatamente o saber da Ciência que se torna objeto de suspeitas, mas sim o que os cientistas, institucionalmente organizados ou não, e seus patrocinadores podem fazer com o conhecimento e o poder que detêm.

Esse conjunto de circunstâncias reflete-se nas tramas endossadas nos conteúdos midiáticos, já que segundo ainda Giddens (2002:29), 'a modernidade é inseparável de sua própria mídia'. Reiterando o que outros estudiosos já ensinaram, para o pensador britânico a multiplicidade de experiências contemporâneas chegam até nós através da mediação dos canais de comunicação cujas mensagens caracterizam-se sobretudo pelo efeito de colagem, no qual ocorre a justaposição de enredos que acaba por gerar uma representação peculiar dos eventos pretensamente retratados, interferindo nas possíveis interpretações dos acontecimentos e ainda a intrusão de eventos distantes na consciência cotidiana, desterritorializando os fatos, criando a sensação de que cada um constitui-se em cidadão do mundo. Em resultado, 'nas condições da modernidade, os meios de comunicação não espelham realidades, mas em parte as formam', criando a falsa percepção da inexistência de um ‘outro' em prol da composição de um 'nós' idealizado e frágil às especulações mais aprofundadas (Giddens, 2002:13), o que certamente acrescenta novas dificuldades na constituição das identidades e das alteridades (Hall, 1997).

Em outras palavras, o Homem se (re)descobriu e se perdeu numa teia que o situa num mundo mediado pelos canais de comunicação. Esses, por sua vez, redimensionaram a importância das notícias e da difusão do conhecimento que, mais do que nunca, ganhou a dimensão de mercadorias em um contexto no qual a realidade concreta tornou-se fugidia e subordinada às versões virtuais dos acontecimentos (Lyotard, 1986).

Buscando refletir sobre as questões acima expostas, o objetivo desse texto é focar a problemática pós-moderna elegendo para estudo as matérias que tem sido produzidas pela mídia impressa sobre a Ciência e a Tecnologia, contando 
para isso com o olhar assumido pelo jornalismo científico. Tal opção deve-se a dois motivos básicos: o primeiro deles refere-se à centralidade que a Ciência e seus desdobramentos desfrutam na pós-modernidade, corporificando uma instituição instigadora tanto de discursos midiáticos entusiásticos quanto de falas moderadas ou mesmo pessimistas. Um segundo motivo deve-se à circunstância de que a análise de conteúdos das expressões midiáticas corresponde a uma das linhas de pesquisa adotada pelo programa de pósgraduação em Comunicação no qual o autor está engajado, havendo o empenho em avaliar as produções midiáticas em termos conteudísticos e formais.

A posição de destaque que a Ciência ocupa na sociedade contemporânea reflete-se nos produtos oferecidos pela mídia, a qual tem destinado novos e amplos espaços para a veiculação de notícias sobre o tema. A profusão de fontes impõe a necessidade de alguns recortes: primeiramente, decidiu-se pela análise exclusiva das matérias voltadas para o campo das ciências médico-biológicas centrado no corpo humano, já que a perfectibilidade corpórea, a saúde plena e a pretensão da vida que se quer eterna compõem uma tríade insistentemente presente na 'ideologia' pós-moderna (Leal, 2001; Oliveira, 2003). O segundo recorte refere-se às fontes analisadas, adotando-se como corpus para estudo o Caderno FolhaCiência inserido no paulistano Folha de São Paulo, no período de julho de 2001 a julho de $2002^{2}$.

\section{O jornalismo científico na FolhaCiência}

A proposta de enfoque do jornalismo científico coloca em primeiro plano a idéia, ainda corriqueiramente invocada, de que tal prática jornalística corresponde sobretudo à tarefa de tradução dos jargões empregados pelo cientistas para que o leitor leigo tenha condições de entender as reportagens. Postula-se que, bem mais do que isso, o compromisso de divulgação dos mecanismos de produção, aplicabilidade e consumo dos resultados dos saberes e dos produtos científicos exigem a recorrência a estratégias específicas para a formulação de um discurso original, mesmo que baseado nas falas e nos movimentos gerados no interior do campo científico. Nesse sentido, o jornalista científico não é um mero tradutor da Ciência, mas sim um arquiteto de versões midiáticas sobre os 'fatos' científicos (Zamboni, 2001). 
Esse conjunto de procedimentos que leva a informação a ganhar a formatação de notícia, é importante que se ressalte, está inscrito no território da cultura. Se ganhou o sentido de regra enfatizar que o jornalista deve sempre pressupor que seus leitores estão imersos em malhas culturais e que essa circunstância pode levar à ocorrência de 'ruídos' no processo comunicativo (Bueno, 2003), ainda pouca atenção é concedida ao fato de o próprio profissional da comunicação cooptar nas matérias que produz com os valores culturais predominantes na sociedade em que está inserido. Se a comunicação é tida como 'condição matricial da cultura' (Rocha, 2004), julga-se que também é necessário se observar o reverso desta situação: a cultura também é formuladora das teias da comunicação e de seus produtos. Nesse sentido, o texto jornalístico pode ser avaliado como um espelho do momento em que é produzido não só no plano ideológico, mas sobretudo na esfera da cultura. Aceita essa ótica, pode-se conferir um novo campo de questionamento por parte da antropologia da comunicação.

A partir desses supostos é que se busca analisar as matérias veiculadas pela FolhaCiência, caderno inserido na Folha de S. Paulo a partir de meados da década de 1980, momento no qual o jornal experimentou uma profunda reforma gráfica e editorial aos moldes do jornalismo empresarial norteamericano (Silva, 1988 e 1991). Nesse processo, a Folha reivindicou para si o papel de porta-voz privilegiado da pós-modernidade, inclusive no que tange ao caderno aqui analisado3. No plano formal, a proposta do diário para seu caderno especializado é oferecer ao leitor "notícias sobre as últimas descobertas e pesquisas mais recentes e importantes no Brasil e no mundo, com especial atenção para o didatismo e para o uso de recursos visuais na explicação de assuntos complexos" (Folha de S. Paulo, 2004).

No período indicado para estudo, a FolhaCiência contou com 342 números que veicularam um total de 748 matérias, sendo que aproximadamente $95 \%$ delas apontaram como fonte básica de informação instituições científicas, pesquisadores, revistas especializadas ou de divulgação científica e jornais diários estrangeiros, quase todos eles sediados nos Estados Unidos e na Europa Ocidental e isto mesmo quando, ironicamente, as situações, experimentos e personagens retratados estivessem localizados no Brasil ou em outras partes do planeta que não o das fontes exploradas pela Folha. No mesmo 
sentido, quase 60\% das matérias foram indicadas como sendo da editoria do caderno, significando que - segundo o depoimento de um jornalista consultado - os textos foram fornecidos por agências noticiosas ou colhidas em outras fontes e apenas adaptados, se não simplesmente traduzidos - para o leitor brasileiro. Ainda em relação ao conjunto de matérias, 95\% apresenta um caráter predominantemente informativo, situação que se mostra contrária à proposta do novo espírito do jornalismo científico, o qual apregoa a necessidade de o profissional da comunicação posicionar-se frente aos fatos tratados, ‘dialogando' com o leitor com o objetivo não só de favorecer a 'alfabetização científica', mas também de contribuir para a constituição de consciências cidadãs (Capozoli, 2002).

Nesse contexto, do total de matérias apresentadas pelo caderno, 204 (27.2\%) corresponde a iniciativas que articulam as ciências médico-biológicas e as questões suscitadas pelo corpo humano. A intensa presença desse tema na FolhaCiência, espelhando um movimento geral na mídia, revela-se um fato comum em publicações de divulgação científica, já que nada mais chama a atenção do leitor do que as formulações científicas acerca do que lhe é mais íntimo: seu próprio corpo, território no qual frutificam temores e esperanças minimizadas ou exponenciadas pela intensa intervenção da medicina. Nesse movimento pendular entre segurança e risco, torna-se cada vez mais claro que a máxima cartesiana 'penso, logo existo' está sendo substituída pelo princípio cunhado pela fenomenologia segundo o qual 'tenho um corpo, logo existo'. Um corpo que, como se verá, assumiu novas conotações em consequência das recentes descobertas científicas, destacando-se as propostas fornecidas pela biologia molecular.

\section{A ciência do corpo na FolhaCiência}

O corpo humano aflora nas matérias analisadas como um fenômeno que dispõe de uma racionalidade própria, sendo de freqüência comum os textos que anunciam a autonomia do corpo em reagir às agressões externas e ao perigo de desfuncionamento devido a uma causa inerente a ele, buscando atingir o estágio de perfeição através do processo evolutivo. No entanto, tal racionalidade é apresentada como tendo capacidades limitadas, condenando o corpo a ser 
dependente de intervenções especializadas. Assim, multiplicam-se as matérias que informam o leitor sobre novas descobertas da medicina para aperfeiçoar a estrutura corpórea, corrigir seus defeitos e, em última instância, prolongar a vida por um tempo que seria impossível creditar apenas à existência que não tenha se submetido à intervenção científica. $\mathrm{O}$ afã em anunciar a positividade da medicina chega às raias do caderno especializado veicular informações rotuladas posteriormente (sem que no entanto o jornal assumisse tal constatação) como pseudo-ciência, como quando a FolhaCiência noticiou como comprovada a estratégia apregoada por médicos europeus de que, para combater a insônia, bastava que o indivíduo lançasse por alguns minutos raios de luz emitidos por uma lâmpada comum na região anterior do joelho.

O primado da medicina no aperfeiçoamento da vida ganhou destaque maior no período focado mediante a exaltação descomedida dos recentes avanços da biologia molecular. Vistoriando as quase duas décadas de publicação do caderno, nenhum tema ganhou tanto destaque, quer pela extensão de cada uma das notícias quer pela freqüência de enfoque quanto os trabalhos de decodificação do genoma humano, assunto que desde 1998 e até o momento tem sido imperante no caderno. Nesse sentido, é possível afirmar que a ‘ideologia médica', pensada como o predomínio de um determinado paradigma científico ou de um tema (Canguilhem, s.d.), contaminou a imprensa, determinando que a terminologia da 'nova genética' esteja presente, mesmo que como metáfora, em um grande número de matérias, centradas ou não em temas médicos.

Nesse curso, se a biologia molecular tem suscitado tanto furor entre os cientistas, ela também se tornou motivo de verdadeiro culto pela maior parte da comunidade dos jornalistas. Acredita-se que foram raras as vezes que uma situação científica gerou tanta fascinação entre os profissionais da mídia, sobretudo porque fica implícito nos enredos autorizados pelo jornalismo científico que a genética representa a face da Ciência que mais contribui para a firmação do sentimento de segurança, tanto para o momento presente quanto para o futuro vislumbrado. O sequenciamento do genoma humano foi saudado por cientistas e divulgadores científicos como a chave para o conhecimento da vida; nesse processo, James Watson e Francis Crick, os arquitetos da 'dupla hélice' no início da década de 1950, foram resgatados da semi-penumbra 
pública para serem alçados à condição de heróis - ou santos - da pósmodernidade. A FolhaCiência, tão reticente em discorrer sobre a biografia dos 'grandes cientistas', utilizou várias matérias para apresentar ao leitor a trajetória de vida de ambos os cientistas, suas dúvidas existências e suas vinculações com os setores acadêmicos e empresariais.

Nas expressões idealizadoras da mídia impressa, praticamente todos os infortúnios gerados pelo aparato biológico humano já foram ou estão prestes a serem solucionados pela engenharia genética. São muitas as matérias que versam, com sofreguidão, sobre a localização dos cromossomos responsáveis por patologias que a todos causam pesadelos inconfessáveis, do câncer ao mal de Alzaimer, da esquizofrenia à cegueira congênita, do infarto do miocárdio ao acidente vascular-cerebral e a depressão psicológica. Isto sem esquecer que os vírus e bactérias causadoras de várias doenças infecto-contagiosas que ainda não encontraram soluções plenamente eficientes pela medicina, tais como os micróbios da AIDS, do Ebola, da influenza pandêmica, das febres do Nilo e de Llassa, ganharam destaque no momento em que foram objetos de sequenciamento genético total ou parcial, ficando a sensação de que, em breve, as patologias a eles creditadas comporão uma página virada na história sanitária da Humanidade.

O desdobramento lógico para algumas perorações midiáticas é que a Ciência já localizou ou está prestes a identificar a parte do genoma humano ou os mecanismos químico-biológicos do envelhecimento e da morte. Ainda não se chegou ao extremo de se fazer a apologia da morte como um fenômeno superado pela intervenção médica, mas algumas matérias pontificam que, em uma década, a genética estará capacitada para instruir uma medicina preditiva que localizará os genes responsáveis pelas patologias antes que elas se pronunciem no organismo humano e que a engenharia genética intervirá no corpo para retardar os mecanismos do envelhecimento, fazendo o tempo médio de vida estender-se para 120 anos. Várias matérias versam sobre o novo campo de ação da criogenia; se a morte não pode ser evitada nem mesmo nas perorações mais otimistas sobre o porvir, a preservação do corpo ou apenas do cérebro em câmaras de congelamento representa a esperança de que em algum momento, a vida poderá ser um fato eterno. 
O apregoamento jornalístico que, explícita ou implicitamente, versa sobre um mundo sem doenças, sem dores e potencialmente sem mortes e também sobre a perfectibilidade do corpo graças à intervenção especializada parece inesgotável nas mensagens emanadas pelo jornalismo científico. Mesmo que de maneira fragmentada, a representação imperante na mídia divulgadora da Ciência é que o corpo humano se constitui em uma máquina cujas peças e mecanismos já são plena ou pelo menos suficientemente conhecidos pela medicina. Tal presunção gera dois tipos de comportamentos jornalísticos: o primeiro deles é que tudo que é identificado como obstáculo para o avanço médico tem perdido interesse e espaço nas páginas da FolhaCiência. A AIDS, por exemplo, quase não apareceu como desafio ainda não resolvido pela Ciência, sendo o tratamento do assunto quase todo deslocado para outros cadernos do jornal. $\mathrm{O}$ outro comportamento refere-se à produção de matérias entusiasmadas sobre o potencial regenerador do corpo através da recorrência clínica às células-tronco. Pouco as matérias discorrem sobre as dificuldades e riscos na utilização dessas células no 'reparo' do organismo humano, preferindo os jornalistas enfatizarem o sucesso dos experimentos laboratoriais que foram realizados com cobaias e sugerirem que, dentro em pouco, tais recursos estarão à disposição dos enfermos.

O aperfeiçoamento do corpo biológico desdobra-se também na versão midiática de uma Ciência desvendadora e potencialmente reparadora dos verdadeiros ou falsos desfuncionamentos que, localizados na concretude individual, colocam em questionamentos a lógica, a ética, a moral e até os princípios estéticos adotados pelo tecido coletivo. Desde o ano de 200o, quando se festejou o sequenciamento genético humano, ganharam posições de manchetes os textos que veiculam notícias sobre a 'descoberta', dentre outros, dos cromossomos determinantes dos instintos, da homossexualidade, da seleção de parceiros para reprodução, da hipersexualidade, da preguiça, da beleza (?!), dos comportamentos passionais, da agressividade, da necessidade de muitas horas de sono diário, do suicídio e do consumo da cocaína, aventando-se também a localização dos genes determinantes de várias habilidades, como a da inteligência, das habilidades musical e esportiva, da facilidade de solução dos problemas matemáticos e do aprendizado de línguas estrangeiras. Nesse ponto, postulam alguns jornalistas que graças à aplicação do 
conhecimento genético é possível chegar-se a uma sociedade mais perfeita e concatenada, perfazendo uma operação que 'biologiza' o social e, consequentemente, exclui boa parte das responsabilidades individuais e coletivas dos processos de funcionamento e potenciais desajustes que persistem no âmbito grupal.

Nesse cenário repleto de esperanças na biologia molecular à serviço da Humanidade sob a forma de engenharia genética, confidências de verdadeiro encantamento impregnam as matérias jornalísticas analisadas. Uma dessas matérias, assinada por um dos mais destacados jornalistas científicos do país, ao comemorar a localização do responsável pela esquizofrenia, incorporou ao lide da notícia a seguinte afirmação: "poucas empreitadas científicas foram tão desacreditadas quanto a caça ao gene, ou genes, da esquizofrenia", conferindo uma dimensão epopéica à descoberta creditada a uma equipe de cientistas norte-americanos. O deslumbramento midiático também aposta no porvir, como no caso das células-tronco, incitando um jornalista a predizer que estas células 'estão entre as vedetes da medicina do futuro", enquanto que outra matéria informa que as mesmas células podem se tornar "a mais importante descoberta" da Ciência, já que podem se transformar "em qualquer tecido no corpo humano". Outra matéria, que foca os primeiros sucessos de um incipiente experimento laboratorial com ratos, visando a obtenção de um tratamento eficaz para as vítimas da hepatite B, conclui que "apesar de não haver ainda previsão de quando começam os testes em humanos, os cientistas acreditam que serão obtidos resultados semelhantes".

Frente a esses posicionamentos, os especialistas do setor médicobiológico que buscam relativizar a importância das explicações fornecidas pela biologia molecular, tal como o cientista Crodowaldo Pavan, de regra são tratados com um certo toque de deprezo nas páginas da Folha, sendo rotulados automaticamente como 'geneticistas da velha-guarda".

As avaliações otimistas sobre o potencial da prática médica no presente e no futuro contou com um reparo arguto, através do pronunciamento de um dos raros cientistas convocados para publicar um texto na FolhaCiência. Sérgio Danilo Pena, geneticista e professor da Faculdade de Medicina da UFMG, assinalou no artigo intitulado "O novo dualismo da genômica”, publicado em 4 de outubro de 2001, os limites do saber genético e a fragilidade das abordagens 
triunfalistas sobre esse ramal da Ciência, avaliando o sequenciamento genético do Homem como ainda sendo apenas um 'rascunho' e não como uma operação já completada, como sugerem várias matérias jornalísticas analisadas. O caráter contundente do artigo, que rema em sentido contrário ao posicionamento dos jornalistas atuantes no diário sob análise, merece ser reproduzido em parte:

“A publicação recente do primeiro rascunho do genoma humano fortaleceu a noção errônea de que ele constitui a verdadeira essência da natureza humana. Como expressou o bioeticista Alex Mauron, o genoma passou a ser visto como o equivalente secular da alma e tornou-se sinônimo da nossa própria humanidade. Tenho genoma, logo existo.

Esse enfoque 'genomocêntrico' é enganoso e perigoso. Enganoso por sua simplicidade atraente. Perigoso porque, como o cavalo de Tróia, carrega em seu ventre um inimigo: o conceito nocivo do determinismo genético. Torna-se indispensável, então, entender o real significado do nosso genoma para 'nós mesmos' (...).

Por toda a nossa vida, o nosso fenótipo ('nós mesmos') depende da interação do genoma com o ambiente atual e com a seqüência dos ambientes passados, isto é, a nossa biografia”.

É necessário se observar que, distante das páginas da imprensa diária, parece que os próprios jornalistas assumem avaliações mais moderadas, apontando os 'avanços' proporcionados pela medicina genética, ressaltando porém os limites de uma Ciência que, se procedeu à decodificação básica do genoma humano e que tem se empanhado na identificação dos cromossomos que podem estar associados a enfermidades e comportamentos, até o momento elaborou raras e eficientes formas de intervenção na saúde humana. Mais do que isto, alguns livros assinados por profissionais da imprensa, inclusive que atuam ou atuaram na FolhaCiência, dedicam algumas páginas para, não sem um certo sentimento de auto-crítica, a qual é estendida aos cientistas, registrarem a dimensão parcialmente fantasiosa de muitas matérias tematizadas pela genética que são disseminadas pelos meios de comunicação de massa (Tognolli, 2003; Leite, 2003; Teixeira, 2000).

A sensação de segurança inspirada pelo novo poderio da biologia molecular convive com a percepção de risco sobre o alcance intervencionista da Ciência, dos cientistas e das instituições que os patrocinam. Um novo alento tem ganho as vozes que discorrem sobre o potencial dos envolvidos no campo da genética em comportarem uma 'dupla personalidade', incorporando ao mesmo tempo o espírito de Dr. Jekyll e o de Mr. Hyde. Nesse âmbito, mais do que as menções sobre a existência de uma multidão de excluídos que não terão como 
obter os dispendiosos tratamentos que deverão ser proporcionados pela genética e a possibilidade, também no futuro, da instalação de um autoritarismo social em nome da eugenia, o indício de perigo mais acalentado pela mídia tem um nome: clonagem.

As pesquisas voltadas para a clonagem foram inicialmente avaliadas como mais um triunfo da genética, ganhando maior visibilidade na mídia em 1996, quando o biólogo britânico Ian Wilmut apresentou ao mundo o primeiro animal clonado da história, a ovelha batizada com o nome Dolly. Somente em agosto de 2001, momento de veiculação das primeiras notícias que tratavam da clonagem humana, a FolhaCiência abriu espaço para, em nome da bioética, inserir na sua pauta os receios de que a genética poderia desviar-se do caminho de ciência auxiliadora do Homem e, inebriada com sua própria potencialidade, 'produzir' seres humanos segundo uma estratégia que colocaria em risco a dignidade não só de tais criaturas, mas a de todos nós.

Mesmo que de maneira fugidia e ocupando espaços bem menores do que aqueles destinados à celebração da genética, ganhou destaque quase que permanente o médico italiano Severino Antimori que desde abril de 2001, mesmo contra a legislação de seu país e da ameaça de perder o direito de exercer a profissão, declarava que iria sim clonar um ser humano. Nas páginas especializadas da Folha, os textos que tratam do assunto ganham um certo ar de indignação nem sempre escamoteada, inclusive porque, ainda segundo o jornal, 'o futuro chegara' e ele poderia reavivar os pesadelos das práticas nazistas, já que o cientista italiano declarava que sua 'produção' seria 'biologicamente perfeita'. Em resposta, alguns artigos anunciavam que, segundo pesquisadores norte-americanos, se a clonagem humana fosse realmente tentada, levaria ao surgimento de seres aberrantes, já que a biotecnologia disponível resultaria em uma intervenção genética imperfeita, incapaz de impedir a morte do feto ou ainda o nascimento de 'monstros', alcunhando Antimori de 'Dr. Ética maluca”.

Percebendo a ambiguidade de apoiar as propostas da 'nova genética' e ao mesmo tempo mostrar-se temeroso frente à duplicação humana com fins reprodutivos, o caderno especializado novamente quebrou sua rotina ao publicar um artigo assinado pela bióloga e professora da USP Lygia da Veiga Pereira. O texto conta com o propósito de explicar aos leitores o processo de clonagem e desaprovar a proposta de clonagem reprodutiva, acusando os que 
ousassem lançar mão dessa prática como sendo 'pseudocientistas' que poderiam causar um 'grande mal'. A pesquisadora, no entanto, defendeu a clonagem terapêutica, com a utilização de células-tronco extraídas de embriões de até cinco dias de existência, pontificando que "a proibição cega [da clonagem com fins terapêuticos] leva ao atraso da ciência e da melhora da qualidade de vida”.

Pouco tempo depois, a mesma postura foi reiterada por cientistas nacionais e estrangeiros, sendo adotada por praticamente todas as matérias científicas veiculadas pelo jornal. Não obstante, notícias de ocorrência de clonagem reprodutiva em local incerto da Europa Oriental, Estados Unidos, China e Emirados Árabes Unidos foram veiculadas e nunca desmentidas, criando a sensação de que, em algum lugar, estava em curso a gestação de um ser que poderia colocar em xeque os próprios fundamentos éticos, morais e religiosos da Humanidade4.

Nesse cenário, a Folha estampou em seu caderno de ciências parte do pronunciamento do filósofo Roberto Romano, realizado no âmbito de um encontro de bioética, que servia de alerta aos próprios jornalistas: "para ter ética científica, é necessário entender que o cientista está fazendo, sem condena-lo a priori”. Mesmo assim, em abril de 2002, quando Antinori informou que havia secretamente clonado um embrião humano e o implantado no útero de uma mulher, o qual já contava com oito semanas de vida, a FolhaCiência, sem levar em consideração se a possibilidade de a informação ser mentirosa, avaliou que o anúncio "surpreendeu e horrorizou a comunidade científica”, negando-lhe qualquer positividade.

Pouco depois, outra matéria estampada no caderno assim se referiu ao médico italiano:

"Chamar o embriologista italiano Severino Antinori de cientista parece exagero, na opinião de muitos acadêmicos. Cientistas, afinal, costumam pautar sua conduta pela publicação de seus resultados e pela submissão de seus trabalhos ao crivo de seus pares”.

Para reafirmar sua opção, nos dias seguintes às primeiras notícias sobre a clonagem humana, o jornal reproduziu trechos das ponderações do presidente norte-americano. Mesmo que Bush se declare contrário a qualquer modalidade de clonagem, parece que a Folha concorda com alguns itens constantes na exposição do político, principalmente quando ele afirma que "a vida é uma 
criação, não um bem de mercado. Nossos filhos são dádivas e devem ser amados e protegidos, e não produtos a serem projetados e manufaturados”.

$\mathrm{O}$ posicionamento do jornal em combater o risco de arquitetura de um futuro sob a égide avassaladora da ciência, marcado por um teor que para muitos sintoniza-se com o antihumano, contrapõe-se ao perigo de rejeitar uma das possibilidades científicas de ponta. Por isso, apelando para a fala de um outro político, o senador democrata Tom Daschle, a FolhaCiência estampou em suas páginas uma interrogação que os jornalistas não ousaram responder: "vamos impedir o progresso em algumas das doenças mais terríveis conhecidas pelo homem ou vamos permitir que a pesquisa vá em frente?”.

\section{Considerações finais}

O convívio com as novas concepções de segurança e risco é uma das marcas - ou uma das maldições - da cultura pós-moderna. Deslocados para o contexto da mídia, tais valores quase que imperceptivelmente impregnam as matérias veiculadas, sendo que aquelas que versam sobre os saberes e atividades científicas constituem apenas um indício do movimento que está dando conformação específica a todos os produtos elaborados pelos meios de comunicação de massa.

O ‘admirável mundo novo', perversamente prometido por uma parcela considerável da comunidade científica e adotado com maior ou menor intensidade pela imprensa, representa uma versão/avaliação possível dos acontecimentos, preservando nas entrelinhas as angústias e esperança de um tempo que ainda nos parece indecifrável, porque de transição. Nem sempre o caminho de análise aqui adotado é aceito, especialmente pelos pesquisadores biomédicos. Um respeitável cientista brasileiro, que ocupa posição estratégica no gerenciamento de uma das principais instituições médicas nacionais, confidenciou recentemente que evita conceder entrevistas a jornalistas ou saber que suas exposições em eventos científicos serem registradas pela mídia porque suas idéias são corriqueiramente alteradas, criando dificuldades em seu ambiente de trabalho. Para ele, as distorções perpetradas pelo jornalismo devese apenas ao preparo deficiente dos profissionais que cobrem o momento científico. 
Acredita-se que, bem mais do que a capacidade de o profissional da comunicação em entender os temas especializados e elaborar textos para serem lidos pelos leigos, são as lentes culturais que ele mobiliza que definem os conteúdos que assina. Nesse encaminhamento, funde-se num mesmo texto paixão pelas novas conquistas científicas e temor pelo que ela pode proporcionar à Humanidade. Além disso, a inclusão de notícias científicas diversas em uma mesma página e a frágil informação sobre quanto e onde exatamente ocorreram os fatos reportados acabam por produzir uma sensação de 'deslocamento' espaço-temporal que, experimentada pelo leitor, também não se mostra anulado no praticante do jornalismo, interferindo em tudo que redige e na auto-avaliação que faz de seu trabalho.

A apologia do progresso tutorado pela Ciência e pela Tecnologia inevitavelmente flui para as especulações sobre o tempo futuro. Na maior parte das vezes de forma fugidia, os textos científicos elaborados ou reproduzidos pela Folha voltam-se para o porvir, abrigando entusiasticamente em suas mensagens a sensação de segurança e, de forma desolada, a de risco. Nessa senda, as interrogações propostas pelo tempo presente se disseminam e se intensificam em relação ao futuro, sem contudo encontrar possibilidades para respostas convincentes, colocando às claras a mídia atual como produto de um momento cultural no qual confiança e medo mostram-se como as duas faces de uma mesma moeda.

\section{Notas}

(*) Versão original da palestra apresentada no IV Interprograma da Compós realizado em Brasília, em 28 e 29 de Outubro de 2004.

(**) Graduado em História e Ciências Sociais, doutor em Ciências (História Social) pela Universidade de São Paulo; docente do Programa de Pós-Graduação em Comunicação da Faculdade de Arquitetura, Artes e Comunicação e do Programa de Pós-Graduação em Educação para a Ciência da Faculdade de Ciências da Universidade Estadual Paulista (UNESP), campus de Bauru.

(1) No dia 7 de agosto de 1945 as notícias de primeira página do New York Times deixavam claro o posicionamento do jornal, inclusive sobre o uso da tecnologia nuclear. As manchetes foram as seguintes: "First atomic bomb 
dropped on Japan", "Missiles is equal to 20,000 tons of TNT" e "Trumam warns foe of "rain of ruin"”. As manchetes, também de primeira página do dia $10 \mathrm{de}$ agosto foram: "Atom bomb loosed on Nagasaki", "2d big aerial blow" e "Result called good".

(2) A maior parte das análises sobre as matérias da FolhaCiência foram extraídas de uma pesquisa realizada pelo autor (Bertolli Filho, 2003).

(3) Apesar de atualmente ocupar um pequeno espaço no jornal, a FolhaCiência é apresentada pelo Manual de Redação da Folha como sendo um caderno temático, sendo esta designação aqui adotada. Vale ressaltar que, quando ele surgiu, contava até com quatro páginas, geralmente inseridas no final do Caderno Mundo. No decorrer dos anos, porém, as páginas dedicadas à divulgação científica foram sendo restringidas, ocupando em média uma página, sendo metade dela tomada por propagandas. Diferentemente de outros cadernos do jornal, percebe-se que o espaço destinado à Ciência varia conforme a existência ou não de notícias quentes, referentes ou não à temática científica. Assim, no dia 12 de setembro de 2001, quando se apresentou detalhes sobre os ataques terroristas em Nova Yorque e Washington, o noticiário científico ficou restrito a menos de _ de página, enquanto que em agosto do ano seguinte, a FolhaCiência estendeu-se por até quatro páginas para cogitar sobre os possíveis motivos técnicos que causaram o acidente na base de Alcântara, quando um foguete lançador de satélites explodiu ainda na plataforma de lançamento, causando a morte de vários técnicos e ameaçando de cancelamento o projeto espacial brasileiro.

(4) A descontinuidade das notícias, mesmo de um 'tema quente', não permitiu que o leitor da Folha fosse imediatamente alertado que nenhuma das iniciativas de clonagem chegou a termo, sendo que transcorreu alguns meses para se informar que coube aos chineses alcançarem o maior sucesso, produzindo um feto que, ao morrer, contava com cerca de duas centenas de células.

\section{Referências bibliográficas}

Berman, Marshall. Tudo que é sólido desmancha no ar: a aventura da modernidade. São Paulo: Companhia das Letras, 1986.

Bernard, Jean. Esperanças e sabedoria da medicina. São Paulo: Ed. da Unesp, 1998.

Bertolli Filho, Claudio. Jornalismo científico: entre a divulgação e a distorção da ciência. Bauru: FAAC/UNESP, 2003. (Relatório de pesquisa)

Black, Edwin. A guerra contra os fracos: a eugenia e a campanha dos Estados Unidos para criar uma raça dominante. São Paulo: A Girafa, 2003.

Bueno, Wilson da Costa, "O caso do boimate. Uma árvore que dá filé ao milho do tomate. E alguém acreditou nisso", 
wwww.jornalismocientifico.com.br/artigojornacientificowbuenoboimate.htm, capturado em 06/08/2003.

Canguilhem, Georges. Ideologia e racionalidade das ciências da vida. Lisboa: Edições 70, s.d.

Capozoli, Ulisses. “A divulgação e o pulo do gato”. In: Massarani et al. (orgs). Ciência e público: caminhos da divulgação científica no Brasil. Rio de Janeiro: Casa da Ciência/UFRJ, 2002, p. 121-131.

Folha de S. Paulo. Manual da redação. São Paulo: PubliFolha, 2001.

Folha de S. Paulo. "Cadernos diários”, www1.folha.uol.br/folha/conheca/cadernos_diarios.shtml, capturado em o8/10/2004.

Giddens, Anthony. Modernidade e identidade. Rio de Janeiro: Jorge Zahar, 2002.

Hall, Stuart. Identidades culturais na pós-modernidade. Rio de Janeiro: DP\&A, 1997.

Latour, Bruno. Jamais fomos modernos: ensaio de antropologia simétrica. São Paulo: Ed. 34, 2000.

Leal, Ondina Fachel (org.). Corpo e significado: ensaios de antropologia social. $2^{\mathrm{a}}$. ed., Porto Alegre, Ed. da UFRS, 2001.

Leite, Marcelo. O DNA. São Paulo, PubliFolha, 2003.

Lyotard, Jean-François. O pós-moderno. Rio de Janeiro: José Olympio, 1986.

Marx, Karl e Engels, Friedrich. O Manifesto Comunista. Rio de Janeiro: Paz e Terra, 1996.

Oliveira, Luiz Alberto. "Biontes, bióides e borgues". In: Novaes, Adauto (org). $O$ homem-máquina: a ciência manipula o corpo. São Paulo, Companhia das Letras, 2003, p. 139-173.

Rocha, José Carlos. "Comunicação e cultura”, Bauru: Simpósio "Cultura: arte e tecnologia”, 2004. (texto de palestra)

Santos, José Ferreira dos. Pós-modernismo. $2^{\mathrm{a}}$. ed., São Paulo: Brasiliense. 1986.

Silva, Carlos Eduardo Lins da. Mil dias: os bastidores da revolução em um grande jornal. São Paulo: Trajetória, 1988.

Silva, Carlos Eduardo Lins da. O adiantado da hora: a influência americana sobre o jornalismo brasileiro. $2^{\mathrm{a}}$. ed., São Paulo: Summus, 1991. 
Teixeira, Mônica. O Projeto Genoma Humano. São Paulo: PubliFolha, 2000.

Tognolli, Claudio. A falácia genética: a ideologia do DNA na imprensa. São Paulo: Escrituras, 2003.

Zamboni, Lílian Márcia Simões. Cientistas, jornalistas e divulgação científica. São Paulo: Autores Associados/FAPESP, 2001. 